\title{
Nowoczesne metody lutospawania w aspekcie jakości i właściwości połączeń
}

\author{
Modern methods of weldbrazing \\ in the aspect of quality and properties of joints
}

\section{Streszczenie}

Przedstawiono zasadę procesu lutospawania i omówiono podstawowe metody stosowane na skalę przemysłową. Zwrócono szczególną uwagę na metody lutospawania łukowego elektrodą topliwą, zapewniające uzyskanie wymaganej wysokiej jakości (CMT, ColdArc, AC-Pulse), a także lutospawanie laserowe. Rozważono zasady i obszary zastosowania oraz właściwości połączeń lutospawanych, uzyskane w wyniku badań prowadzonych w Instytucie Spawalnictwa.

Słowa kluczowe: lutospawanie; metody niskoenergetyczne; lutospawanie laserowe; właściwości połączeń lutospawanych

\begin{abstract}
It has been presented the fundamentals of weldbrazing process and methods used on an industrial scale has been discussed. Special attention is paid to modern methods of GMA braze welding, assuring high quality (CMT, ColdArc, AC-Pulse), as well as laser brazing. The principles, areas of application and the properties of the braze welded joints, resulting from research conducted at the Institute of Welding have been discussed.
\end{abstract}

Keywords: weldbrazing; low energy methods; laser beam weldbrazing; weldbraze properties

\section{Wstęp}

Coraz wyższe wymagania użytkowe stawiane wyrobom i konkurencja na globalnym rynku spowodowały wzrost zainteresowania elementami konstrukcyjnymi (blachy, kształtowniki itp.) z powłokami ochronnymi (cynkowe, aluminiowe, organiczne) i ze stali odpornych na korozję, szczególnie w przemyśle motoryzacyjnym (koncerny oraz firmy kooperujące), elektromaszynowym (instalacje wentylacyjne, urządzenia klimatyzacyjne i chłodnicze), okrętowym i spożywczym (zbiorniki, kontenery), w produkcji sprzętu AGD, w przemyśle meblarskim i w budownictwie (pokrycia dachów i elewacji, instalacje wodne). Zainteresowaniem cieszą się metody i sposoby, umożliwiające uzyskanie wysokiej jakości połączeń z blach stalowych w zakresie grubości od 0,7 do $3 \mathrm{~mm}$, zwłaszcza z powłokami ochronnymi. Coraz częściej, szczególnie w przemyśle motoryzacyjnym jest więc stosowane lutospawanie. Wykorzystywane do niedawna lutospawanie elektrodą topliwą w osłonie gazu obojętnego łukiem standardowym nie dawało zadowalających efektów. Składały się na to problemy ze wprowadzeniem do złącza zbyt dużej ilości ciepła, czego rezultatem były odkształcenia, uszkodzenia powłoki cynkowej, a także towarzyszące procesowi odpryski, które dodatkowo uszkadzają powłokę ochronną i znacznie pogarszają estetykę połączeń, a ich usunięcie jest operacją czasochłonną i nie zawsze skuteczną.
Zrobotyzowane procesy łączenia elementów, dominujące w przemyśle motoryzacyjnym, wymagają wysokiej stabilności procesu, czego nie zapewniało lutospawanie tradycyjną metodą MAG.

Odpowiedzią na to zapotrzebowanie przemysłu samochodowego było opracowanie i wdrożenie do powszechnego stosowania tzw. odmian niskoenergetycznych, wśród których najczęściej stosowane są techniki CMT i ColdArc. Badania technologiczne prowadzone uprzednio w Instytucie Spawalnictwa oraz doświadczenia przemysłowe i analiza literatury technicznej wskazują, że zastosowanie niskoenergetycznych wariantów lutospawania elektrodą topliwą pozwala na znaczne zmniejszenie odkształceń spawanych detali, ograniczenie rozprysku, a co się z tym wiąże znaczne polepszenie estetyki. Wyniki badań wykazały ponadto, że zastosowanie tych metod w przypadku blach z powłokami ochronnymi pozwala zmniejszyć uszkodzenie powłoki [1 $\div 3]$. Najnowszym rozwiązaniem w zakresie niskoenergetycznych odmian lutospawania elektrodą topliwą jest zastosowanie prądu pulsującego o zmiennej biegunowości (AC Pulse, Cold Process, CMT Advanced) $[4 \div 5]$.

Bardzo dobrą jakość połączeń elementów wykonanych z blach ocynkowanych zapewnia lutospawanie plazmowe proszkowe [6]. Możliwe jest uzyskanie złączy doczołowych

Dr inż. Tomasz Pfeifer, Dr inż. Sebastian Stano - Instytut Spawalnictwa.

Autor korespondencyjny/Corresponding author. Tomasz.Pfeifer@is.gliwice.pl 
i zakładkowych charakteryzujących się bardzo wysoką estetyką i własnościami wytrzymałościowymi. Odpowiedni dobór parametrów zapewnia zachowanie warstwy cynku bez uszkodzeń - proces lutospawania jest bardzo szybki, a cynk nie zdąży odparować. Proces stosowany jest głównie na stanowiskach zrobotyzowanych, jednakże w przypadku napraw wykorzystywane jest lutospawanie ręczne.

$\mathrm{Na}$ szczególną uwagę zasługuje technologia lutospawania laserowego, polegająca na uzyskaniu połączenia w wyniku stopienia materiału dodatkowego ciepłem wiązki promieniowania laserowego, oddziałującego na spoiwo i materiał podstawowy. Ciepło to powoduje topienie spoiwa oraz podgrzanie łączonych elementów w celu aktywowania procesów kapilarnych i dyfuzji pomiędzy ciekłym lutem a materiałem podstawowym. Lutospawanie zapewnia zachowanie powłoki cynkowej w stanie nienaruszonym oraz bardzo dobrą jakość i estetykę, a także własności mechaniczne połączeń $[7,8]$.

W niniejszym artykule scharakteryzowano krótko poszczególne metody lutospawania i omówiono wyniki przeprowadzonych w Instytucie Spawalnictwa badań technologicznych z zastosowaniem lutospawania łukowego elektrodą topliwą w osłonie gazu obojętnego i aktywnego (wraz z odmianami niskoenergetycznymi), a także lutospawania laserowego blach ocynkowanych o grubości do 1,5 $\mathrm{mm}$. Przedstawiono i omówiono wyniki badań strukturalnych i mechanicznych połączeń lutospawanych.

\section{Przegląd metod lutospawania}

Lutospawanie można określić jako „lutowanie twarde niekapilarne realizowane metodą spawania" [9]. Proces ten polega na wykorzystaniu w metodach spawania spoiw o temperaturze topnienia znacznie niższej od temperatury topnienia materiału podstawowego, co powoduje, że mechanizm powstawania połączeń jest taki sam jak przy lutowaniu. Ze względu na stosowane źródła ciepła lutospawanie dzieli się na: płomieniowe, łukowe i laserowe. Wśród metod łukowych najczęściej stosowane jest lutospawanie $\mathrm{w}$ osłonie gazów oraz lutospawanie plazmowe proszkowe.

\section{Lutospawanie gazowe}

Jest to podstawowa metoda łączenia rur ocynkowanych (grubość warstwy cynku od 100 do $130 \mu \mathrm{m}$ ), stosowanych powszechnie w instalacjach grzewczych, wody pitnej, wody chłodzącej i ściekowej, w instalacjach przeciwpożarowych i sprężonego powietrza [11]. Krawędzie rur przygotowuje się jak do spawania, a proces łączenia odbywa się wg zasad lutowania twardego lub wysokotemperaturowego (temperatura likwidus lutu powyżej $900{ }^{\circ} \mathrm{C}$ ). Do lutospawania stosuje się płomień utleniający. Proces prowadzi się techniką w "lewo", tak aby lut (najczęściej mosiężny) znajdował się przed płomieniem palnika, poruszającego się od strony prawej do lewej. Złącza rur o grubości ścianki do $4 \mathrm{~mm}$ można uzyskać jednym ściegiem. Podczas lutospawania należy dodatkowo uzupełniać ilość topnika, przez wprowadzenie go za pośrednictwem lutu. Uzupełniania nie wymagają luty otulone cienką i elastyczną warstwą topnika. Metoda ta zapewnia uzyskanie poprawnych połączeń pod warunkiem przestrzegania ściśle określonych wytycznych technologicznych (przygotowanie i oczyszczenie krawędzi, odstęp pomiędzy elementami, właściwie wyregulowany płomień, odpowiednia technika lutospawania). Niestosowanie się do wytycznych technologicznych może doprowadzić do uzyskania połączeń z niezgodnościami, przede wszystkim z brakiem szczelności.

\section{Lutospawanie łukowe}

Jest stosowane najczęściej do łączenia elementów o niewielkich grubościach, wykonanych z blach ze stali niestopowych, niskostopowych i stopowych (grubość $0,2 \div 3 \mathrm{~mm}$ ) oraz stali z powłokami cynkowymi (grubość powłoki od 5 do $100 \mu \mathrm{m}$ ) oraz aluminiowymi [9-10]. Lutospawanie łukowe może być również stosowane do łączenia ze sobą materiałów o skrajnie odmiennych właściwościach fizyko-chemicznych, np.: blach stalowych z elementami miedzianymi [13], blach stalowych $z$ aluminium [14], stali z żeliwem, czy do napawania elementów ze stali o ograniczonej spawalności lub stali niespawalnych (zapewnienie odpowiednio niskiego współczynnika tarcia ślizgowego). Ponadto lutospawanie stosuje się do regeneracji elementów odlewanych z materiałów uznawanych za trudno spawalne lub niespawalne [9-10]. Lutospawanie łukowe jest najczęściej realizowane przy zastosowaniu spoiw na bazie miedzi elektrodą topliwą w osłonie gazu (oraz odmianami metody MIG/MAG), rzadziej metodą TIG i plazmową.

\section{Lutospawanie elektrodą topliwą w osłonie gazu}

Jest alternatywną metodą dla spawania łukowego cienkich blach stalowych ze stali niestopowych i niskostopowych, a także cienkich blach zabezpieczonych różnorodnymi powłokami. Jego cechy charakterystyczne w porównaniu do spawania to $[9,10]$ :

- niewielka ilość dostarczonego ciepła, co ma szczególne znaczenie przy łączeniu cienkich blach (znaczne zmniejszenie odkształceń);

- minimalne uszkodzenie powłoki antykorozyjnej na materiale podstawowym w przypadku lutospawania blach stalowych z powłokami;

- stabilne jarzenie łuku i minimalna ilość odprysków;

- możliwość uniknięcia stopienia krawędzi łączonych elementów;

- wysoka wydajność procesu i dostateczna wytrzymałość wykonanych złączy;

- estetyczny wygląd lutospoin i łatwa ich obróbka mechaniczna;

- możliwość łączenia materiałów różnoimiennych i materiałów trudno spawalnych;

- znacznie mniejsza, niż przy spawaniu, ilość wydzieleń dymów i pyłów, zwłaszcza podczas łączenia blach ocynkowanych.

Lutospawanie łukowe MIG/MAG polega na stapianiu drutu elektrodowego (lutu) na materiał łączony ciepłem łuku spawalniczego, jarzącego się pomiędzy drutem a materiałem, w osłonie gazu ochronnego (rys. 1). Lutospoina powstaje więc $w$ wyniku zwilżenia przez stopione spoiwo powierzchni materiału łączonego podgrzanego ciepłem łuku oraz procesu wzajemnej dyfuzji składników tych materiałów. Najczęściej stosowanymi materiałami dodatkowymi są spoiwa na bazie miedzi o temperaturze topnienia nie przekraczającej $1050{ }^{\circ} \mathrm{C}$. Wśród nich najliczniejszą i najczęściej stosowaną grupę stanowią spoiwa z brązu krzemowego typu CuSi3, CuSi3Mn1, CuSi3Mn1Al1.5, CuSi3Mn7. Znalazły one bardzo szerokie zastosowanie przede wszystkim w przemyśle motoryzacyjnym do łączenia cienkościennych elementów karoserii samochodowych z blach ocynkowanych galwanicznie i ogniowo. Są również zalecane do lutospawania cienkich blach ze stali nierdzewnych $[9,10]$.

Kolejną popularną grupę spoiw do lutospawania MIG/ MAG stanowią brązy aluminiowe $z$ domieszkami m.in.: manganu, żelaza lub niklu. Najczęściej stosowanymi spoiwami są brązy typu: CuAl8, CuAl8Ni2, CuAl5Mn1Ni1, CuAl9Ni5Fe, CuAl9Fe. Są one zalecane do lutospawania blach stalowych aluminiowanych i ocynkowanych, a ich wytrzymałość do- 


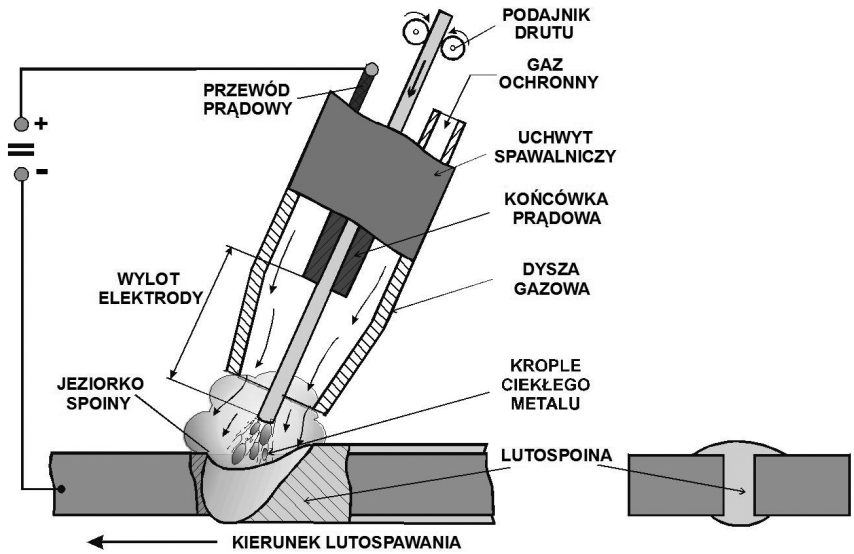

Rys. 1. Przebieg procesu lutospawania łukowego w osłonie gazu ochronnego metodą MIG/MAG wraz z przekrojem złącza doczołowego [4]

Fig. 1. Scheme of gas metal arc welbrazing (GMA) process and the cross section of the joint

chodzi nawet do $700 \mathrm{MPa}$ [9]. W procesach lutospawania MIG/MAG jako gaz osłonowy najczęściej jest stosowany argon, a także następujące mieszanki: $\mathrm{Ar}+(1 \div 3) \% \mathrm{CO}_{2}$ i $\mathrm{Ar}$ $+(1 \div 2) \% \mathrm{O}_{2}$

Obecnie lutospawanie prowadzone jest najczęściej prądem pulsującym, nieco rzadziej prądem stałym (łukiem zwarciowym), z biegunowością dodatnią lub ujemną na elektrodzie. Nowoczesne źródła do spawania elektrodą topliwą w osłonie gazów wyposażone są w specjalne programy dedykowane procesowi lutospawania. Programy te, a właściwie specjalistyczne linie synergiczne, stanowią cechę charakterystyczną danego producenta urządzenia. Coraz częściej zamiast o linii synergicznej mówi się o metodzie spawania / lutospawania. Najpopularniejsze są tzw. „procesy niskoenergetyczne MIG/MAG", w których dzięki zastosowaniu zaawansowanego sterowania parametrami napięcia łuku i natężenia prądu ilość ciepła wprowadzonego do złącza jest ograniczana do minimum. Dzięki tak precyzyjnemu sterowaniu przebiegiem parametrów prądowo-napięciowych uzyskano bardzo dobrą jakość elementów ocynkowanych galwanicznie i ogniowo oraz możliwe stało się łączenie aluminium ze stalą $[1 \div 3]$. Spośród "metod niskoenergetycznych" najlepsze wyniki lutospawania uzyskano za pomocą odmian CMT (z ang. Cold Metal Tranfer) i ColdArc. Umożliwiają one osiągnięcie bardzo dobrej estetyki połączenia, zmniejszenie odkształceń termicznych oraz zapewnia minimalne uszkodzenie warstwy materiału powłoki (cynk, aluminium, powłoki wielofazowe

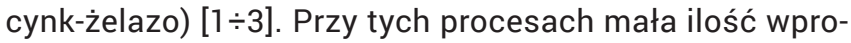
wadzonego ciepła jest korzystna - nawet nie stykające się ze sobą brzegi elementów o bardzo małej grubości nie ulegają nadtopieniu, natomiast ilość ciepła jest wystarczająca do stopienia dość znacznej objętości lutu, co umożliwia tzw. „mostkowanie” czyli polutowanie elementów oddzielonych szczeliną nawet do $2 \mathrm{~mm}$.
Najnowszym rozwiązaniem w zakresie niskoenergetycznych odmian lutospawania elektrodą topliwą jest zastosowanie prądu pulsującego o zmiennej biegunowości (AC Pulse, Cold Process, CMT Advanced - nazwy linii synergicznych). Zastosowane do tego celu musi być urządzenie, zapewniające uzyskanie prądu przemiennego, o zmiennym udziale biegunowości ujemnej [4,5]. Ten sposób kształtowania przebiegu prądu i napięcia zapewnia mniejszą ilość wprowadzonego ciepła, co pozwala na minimalizację uszkodzenia powłoki ochronnej i uzyskanie znacznie mniejszych odkształceń termicznych.

\section{Lutospawanie plazmowe}

Polega na wykorzystaniu ciepła skoncentrowanego łuku elektrycznego do podgrzania łączonych elementów i stopienia materiału dodatkowego w postaci proszku lub drutu o temperaturze topnienia niższej od materiału podstawowego [6]. Ciepło łuku plazmowego aktywuje procesy kapilarne (zwilżanie, rozpływność spoiwa) oraz zjawiska dyfuzji pomiędzy lutem twardym a materiałem podstawowym, tak jak ma to miejsce w procesach lutowania twardego. Do lutospawania, podobnie jak w przypadku metody MIG/MAG, stosowane są urządzenia uniwersalne, przeznaczone przede wszystkim do spawania lub napawania. Proces lutospawania plazmowego, zarówno proszkiem jak i drutem, prowadzony jest w sposób zmechanizowany lub zrobotyzowany. Przeprowadzone badania lutospawania blach stalowych ocynkowanych o grubości 0,9 mm wykazały, że istnieje wąski zakres parametrów technologicznych, zapewniający wykonanie prawidłowego połączenia i dobrą jakość [6]. Zastosowanie odpowiedniej technologii nie powoduje uszkodzenia powłoki cynkowej i odkształceń elementów. W niektórych przypadkach stosowane jest lutospawanie ręczne (materiał w postaci drutu). W Instytucie Spawalnictwa opracowano technologię lutospawania plazmowego z dodatkiem drutu bezkońcowej taśmy tnącej do styropianu, wykonanej z taśmy ze stali NC 10, o grubości $0,25 \mathrm{~mm}$. Ledeburytyczna stal chromowa NC10 stosowana jest na narzędzia do cięcia o wysokiej wydajności, noże do cięcia blach, narzędzia do gwintowania, ciągadła do drutu, rolki formujące. Jej spawanie jest bardzo trudne ze względu na niebezpieczeństwo powstawania pęknięć. Zastosowanie lutospawania plazmowego, ze względu na bardzo małą ilość wprowadzonego ciepła umożliwiło uzyskanie połączenia spełniającego wymagania producenta taśmy (trwałość).

\section{Lutospawanie laserowe}

W procesie lutospawania laserowego, rozogniskowana wiązka laserowa topi podawany w sposób ciągły materiał dodatkowy w postaci drutu, podgrzewając równocześnie materiał łączony umożliwiając aktywację procesów kapilarnych (rys.3). Ochronna powłoka cynkowa pozostaje praktycznie nienaruszona, a lico lutospoiny jest gładkie i równomierne Pozwala to, w większości przypadków, na przeprowadzenie bezpośrednio po procesie lutospawania laserowego operacji nakładania powłoki lakierniczej, bez zastosowania specjalnych, dodatkowych operacji.

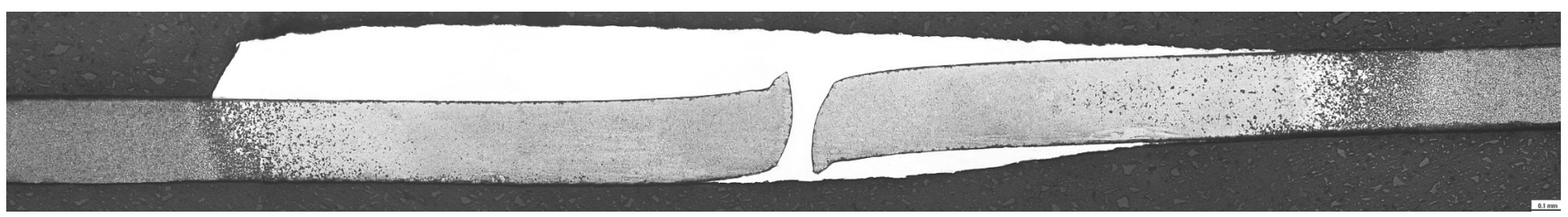

Rys. 2. Mikrostruktura złącza doczołowego blach ze stali NC10 o grubości 0,25 lutospawanego plazmowo z dodatkiem drutu, traw. Nital, pow. $100 \mathrm{x}$

Fig. 2. Microstructure of $0,25 \mathrm{~mm}$ thick NC10 steel butt joint weldbrazed using plasma method, etched with Nital, magnification $100 x$ 


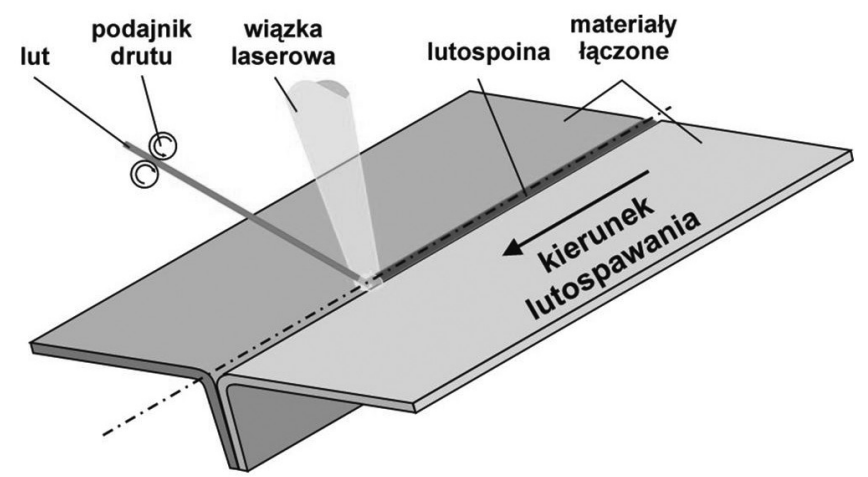

Rys. 3. Przebieg procesu lutospawania laserowego [7] Fig. 3. Scheme of laser weldbrazing process [7]

Jako źródła promieniowania laserowego mogą być wykorzystywane praktycznie wszystkie lasery przemysłowe stosowane w spawalnictwie. Jednakże ze względu na długość fali promieniowania laserowego i związane $z$ tym absorpcje promieniowania laserowego przez miedź i jej stopy oraz możliwości transportu promieniowania laserowego światłowodem do głowicy roboczej i miejsca obróbki, do procesów lutospawania laserowego stosuje się lasery na ciele stałym (lasery dyskowe, lasery włóknowe) oraz lasery diodowe. W kompletach oferowane są stanowiska zrobotyzowane, w których lasery współpracują z systemem sterowania robota przemysłowego, umożliwiając poprawną pracę sytemu i stosunkowo łatwe programowanie. Dodatkowo, lasery te mogą być wyposażone w dodatkowe wyjścia optyczne i światłowody, do których mogą być podłączone kolejne, różne głowice technologiczne znajdujące się na tym samym lub innym stanowisku zrobotyzowanym. Pozwala to na zoptymalizowanie czasu pracy rezonatora i jego maksymalne wykorzystanie, nawet $\mathrm{w}$ trakcie przestojów związanych ze zmianą detalu czy programu.

Do prowadzenia procesu lutospawania laserowego niezbędna jest odpowiednia głowica technologiczna umożliwiająca uzyskanie odpowiedniej średnicy plamki wiązki laserowej w obszarze lutospawania oraz podajnik materiału dodatkowego - drutu do obszaru oddziaływania wiązki laserowej. Podajnik drutu ma za zadanie stabilnie podawać materiał dodatkowy umożliwiając jego równomierne stapianie. Zapewniają to wysokiej jakości podajniki typu push-pull, które posiadają dodatkowe rolki ciągnące, zlokalizowane w bliskiej odległości od obszaru spawania tak, aby zminimalizować opory i niestabilność podawania drutu. Wymagania te spełniają laserowe głowice technologiczne przeznaczone do spawania z materiałem dodatkowym w postaci drutu, gdzie rolki podajnika umieszczone są bezpośrednio przy głowicy spawalniczej a drut podawany jest do ogniska wiązki laserowej pod kątem ok. 45 stopni. Niezwykle użytecznym rozwiązaniem jest zastosowanie głowicy z elektryczną zmianą położenia soczewki kolimatora, umożliwiającej regulację średnicy plamki wiązki laserowej (stopnia jej rozogniskowania) oddziałującej na końcówkę drutu (rys. 4a). W przypadku braku takiego systemu, zmianę średnicy plamki wiązki laserowej uzyskuje się poprzez podniesienie lub obniżenie całej głowicy, co związane jest każdorazowo z koniecznością zmiany położenia końcówki podajnika drutu. Bardziej zaawansowane systemy mogą być wyposażone $\mathrm{w}$ głowice laserowe $\mathrm{z}$ układem podawania drutu, w którym końcówka drutu jest wykorzystywana jak dotykowy czujnik śledzenia złącza (rys. 4b).

Proces lutospawania laserowego jest ciągle doskonalony z wykorzystaniem nowych typów laserów, nowych głowic spawalniczych i systemów zrobotyzowanych. Obecnie rozwijany jest system lutospawania wielowiązkowego. W roz-
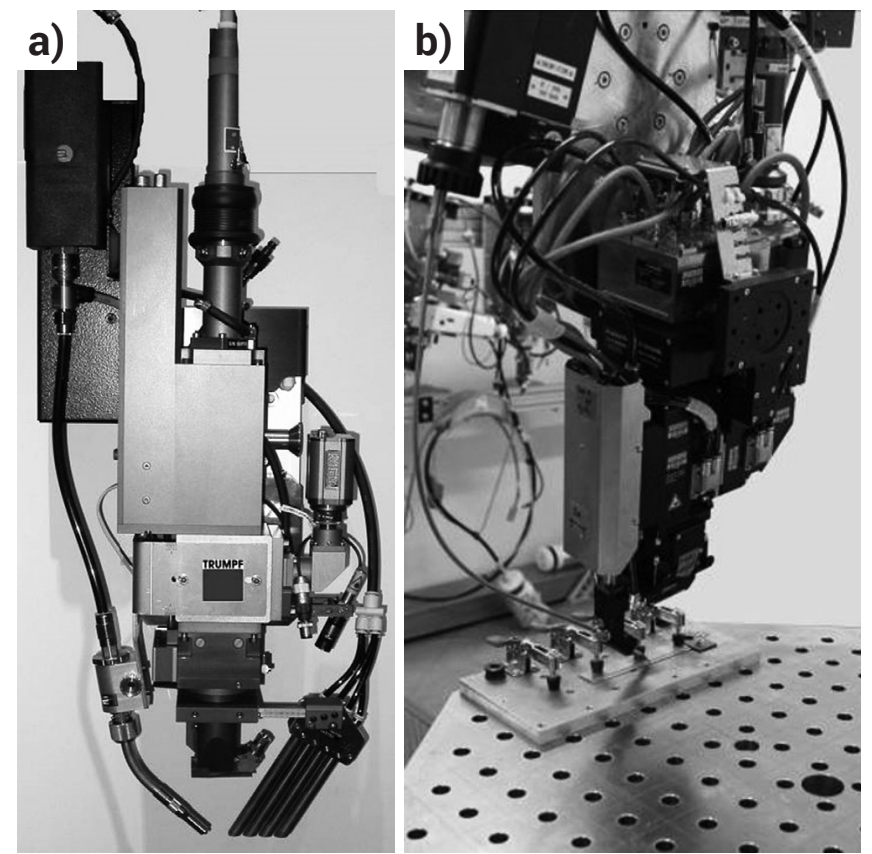

Rys. 4. Głowica laserowa z systemem podawania drutu oraz elektrycznym systemem ustawiania stopnia rozogniskowania wiązki laserowej (a) i głowica do spawania i lutospawania z materiałem dodatkowym w postaci drutu z taktylnym układem śledzenia złącza (b) Fig. 4. Laser head with wire feeding and electrical defocusing system (a) and the laser head for welding and weldbrazing using wire tactile sensing system (b)

wiązaniu tym wykorzystano możliwości konstrukcyjne laserów włóknowych oraz specjalnej konstrukcji światłowody, które umożliwiają transport trzech wiązek laserowych wytwarzanych niezależnie w rezonatorze lasera do głowicy roboczej (rys. 5). Na powierzchni elementu obrabianego optyka procesowa tworzy przypisany każdej z wiązek obszar oddziaływania o określonych parametrach, tworząc dwa małe obszary oddziaływania wiązki laserowej, w których następuje wstępne czyszczenie powierzchni oraz jej podgrzanie i szerszy obszar oddziaływania wiązki głównej, w którym następuje dalsze podgrzewanie elementów lutospawanych oraz bezpośrednie topienie materiału dodatkowego [12].

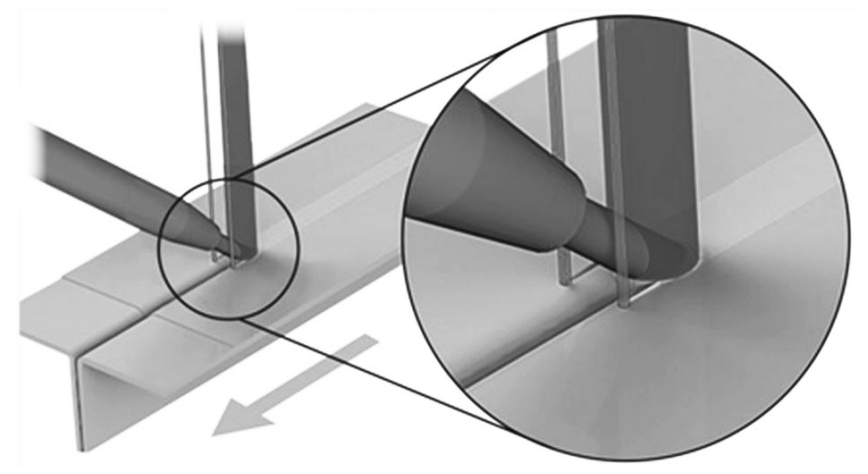

Rys. 5. Schemat procesu lutospawania za pomocą wielokrotnej wiązki laserowej [12]

Fig. 5. The scheme of weldbrazing process with the use of multiple laser beam [12]

Poniżej przedstawiono wybrane wyniki badań materiałowo - technologicznych, prowadzonych w Instytucie Spawalnictwa w zakresie lutospawania elektrodą topliwą w osłonie gazu z zastosowaniem niskoenergetycznych odmian procesu, a także w zakresie lutospawania laserowego. 


\section{Badania materiałowo technologiczne procesów lutospawania w Instytucie Spawalnictwa}

W Instytucie Spawalnictwa badania w zakresie lutospawania rozpoczęto od badań technologicznych zrobotyzowanego lutospawania łukowego metodą MIG prądem pulsującym złączy doczołowych i zakładkowych blach stalowych o grubości 1,5 mm z powłoką cynkową.

Uzyskane wyniki wykazały, że proces lutospawania przebiegał stabilnie - złącza wykazały dobrą jakość i wysoką estetykę. Proces ten wymaga jednakże precyzyjnego doboru parametrów technologicznych w bardzo wąskim zakresie. Z uwagi na wysoką rzadkopłynność spoiw na bazie miedzi (CuSi3Mn1) każde odstępstwo od parametrów uznawanych za najkorzystniejsze (wyznaczone w trakcie badań) powodowało powstawanie niezgodności spawalniczych takich jak: nadmierny nadlew lica i wyciek od strony grani, nadtopienie brzegów materiału podstawowego, przepalenia blach, brak zwilżalności łączonych brzegów blach, rozpryski itp. Przeprowadzone badania mechaniczne połączeń wykazały, że wytrzymałość statyczna na rozciąganie złączy doczołowych wynosi od $350 \div 450 \mathrm{MPa}$, a złączy ze stali nierdzewnej od $270 \div 350 \mathrm{MPa}$. Plastyczność połączeń jest wysoka - możliwe jest uzyskanie kąta gięcia złączy doczołowych $180^{\circ}$, za wyjątkiem złączy, w których doszło do nadmiernego nadtopienia materiału podstawowego i jego rozpuszczenia się w ciekłym lucie, co doprowadziło do wydzielenia się kruchych faz międzymetalicznych. W tym przypadku kąt gięcia wynosił maksymalnie $80^{\circ}[9]$.

Przeprowadzone badania metalograficzne mikroskopowe wykazały, że niewielka ilość wprowadzonego ciepła do złącza lutospawanego powoduje niewielkie zmiany w SWC oraz powstanie struktury złożonej z ferrytu i bainitu, a także nieznaczny rozrost ziarna [9]. Strefa przejścia (materiał podstawowy - lut) widoczna jest na zdjęciach metalograficznych jako wąska, ciemna, ciągła warstewka (rys. 6a). Tworzenie się tej złożonej fazy międzymetalicznej zachodzi prawdopodobnie w wyniku reakcji bezpośredniego oddziaływania ciekłego lutu i materiału podstawowego (rekcja dyfuzyjna) oraz częściowego rozpuszczenia się materiału podstawowego w ciekłym lucie i krystalizacji warstwy fazy międzymetalicznej na ściankach materiału podstawowego jako fazy o tzw. niekongruentnej topliwości (nie występuje w stanie ciekłym przy stężeniu składników odpowiadających jej składowi chemicznemu) $[9,10]$.W strukturze obszaru lutospoiny można wyróżnić jasne ziarna miedzi $(\alpha)$ (pomarańczowe) oraz rozmieszczone w całej objętości drobne i bardzo drobne globularne ciemne fazy (rys. 6b). Widać charakterystyczną strukturę dendrytyczną. Dendryty te o zróżnicowanym ułożeniu osi głównych posiadają rozbudowany układ ramion wtórnych (rys. 6b). W strukturze tej obserwuje się również mikrosegregację pierwiastków na granicach kryształów (rys. 6c). Ujawniono również bardzo drobne wydzielenia złożonych faz międzymetalicznych, opartych głównie na miedzi (ok. 67 \%) oraz żelazie (ok. 15\%) oraz na fosforku miedzi $\mathrm{Cu}_{3} \mathrm{P}$ (rys. 7). Mikroanaliza składu chemicznego obszaru lutospoiny potwierdziła występowanie roztworu stałego złożonego z: krzemu, manganu oraz żelaza, umiejscowionego $\mathrm{w}$ osnowie dendrytów. Ponadto w strukturze lutospoiny znajdują się wydzielenia fazy $\chi$ oraz liczne drobne fazy międzymetaliczne o wysokiej zawartości żelaza [9].

Uzyskane wyniki badań zostały następnie wdrożone do praktyki przemysłowej. Jako przykłady można wymienić [10]:

- opracowanie technologii lutospawania wsporników do belki poprzecznej zderzaka samochodu dostaw-
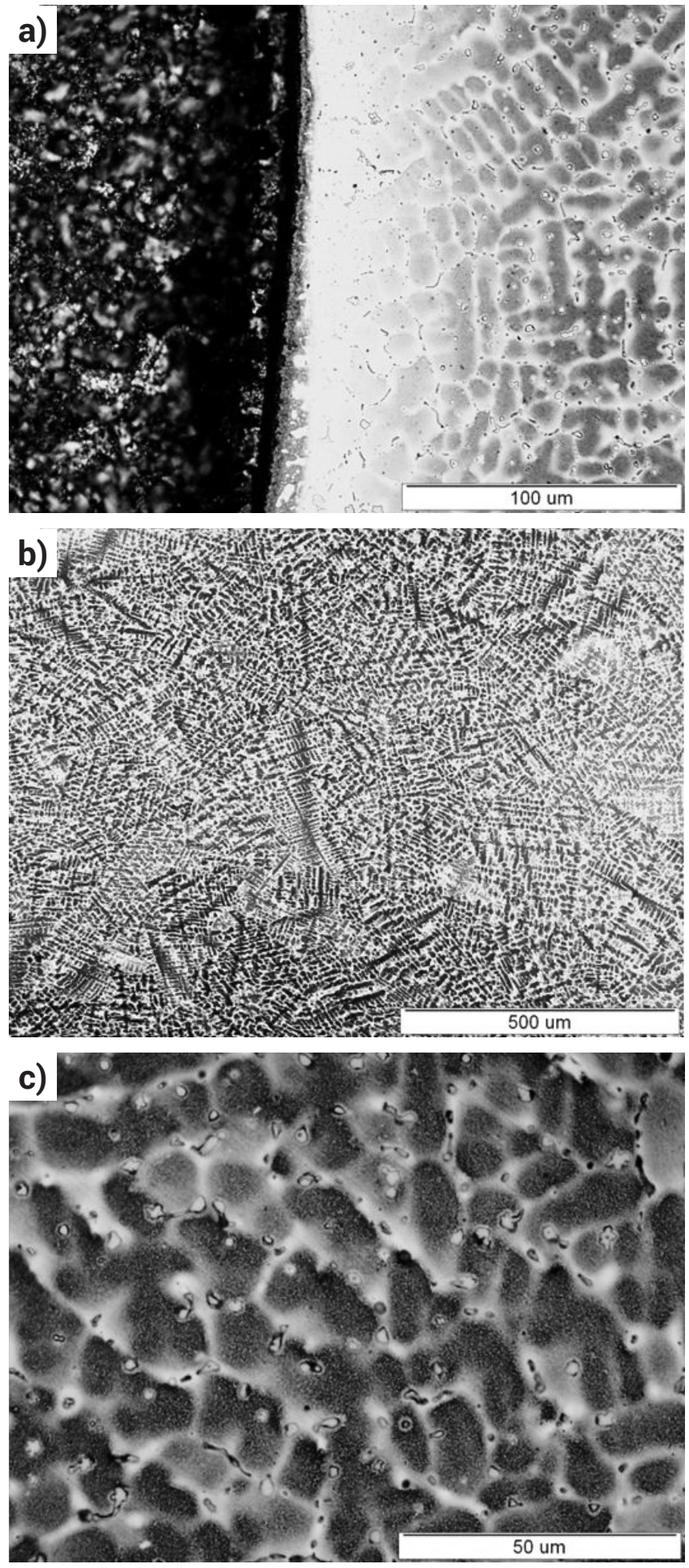

Rys. 6. Mikrostruktura złącza doczołowego blach stalowych ocynkowanych o grubości 1,5 mm, lutospawanego metodą MIG prądem pulsującym: strefa przejścia od materiału do lutospoiny (a), lutospoina $(b, c)$

Fig. 6. Microstructure of $1,5 \mathrm{~mm}$ thick zinc coated steel butt joint MIG weldbrazed using pulsed current: transition zone (a), weldbraze $(b, c)$

czego, wykonanych ze stali o podwyższonej wytrzymałości bez powłoki ochronnej (minimalizacja odkształceń);

- opracowanie technologii łączenia elementów przekładni (lutospoina pachwinowa) odlewu z żeliwa szarego ZL-250 z elementami konstrukcyjnymi ze stali C45;

- opracowanie technologii napawania (natapiania) walców (sworzni) zwałowarko - ładowarki ze stali 42CrMo4V z zastosowaniem spoiwa typu CuAl8. 


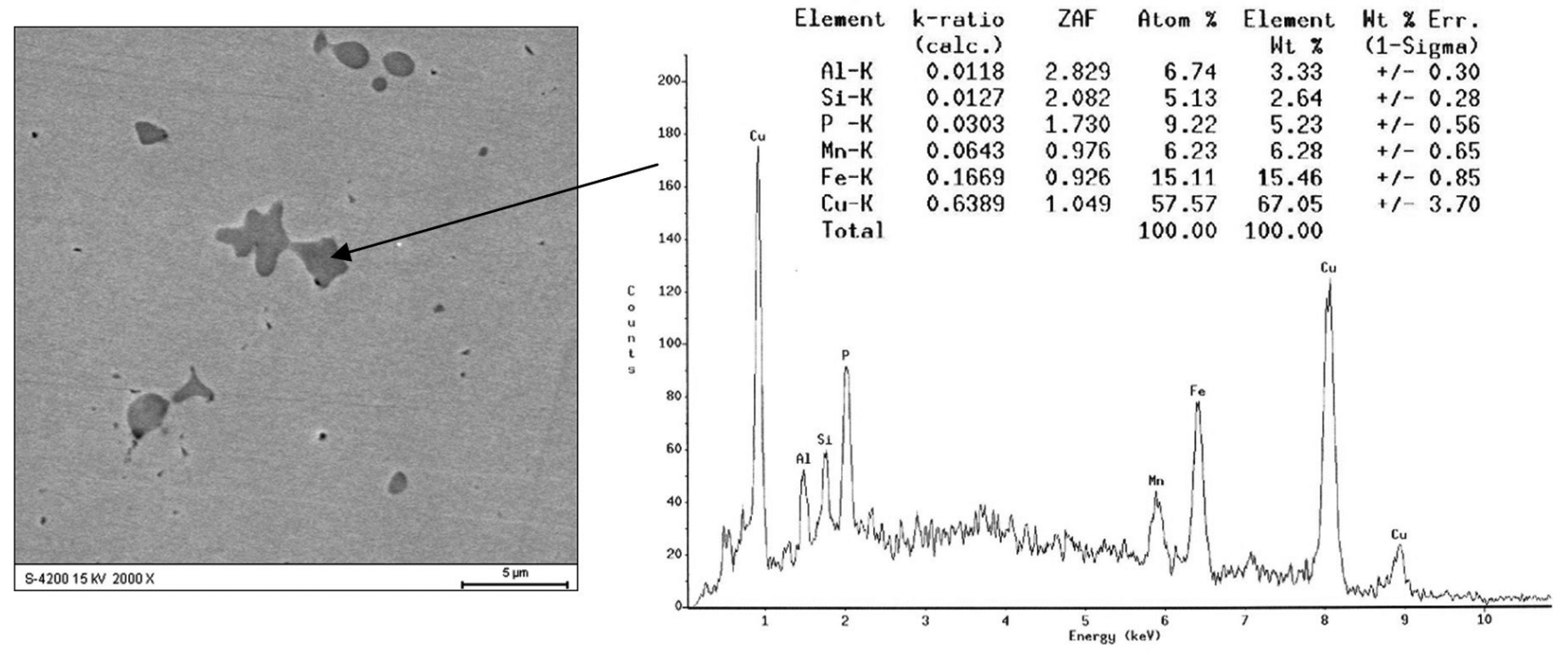

Rys. 2. Wyniki mikroanalizy rentgenowskiej wydzieleń w lutospoinie

Fig. 2. Results of X-ray microanalysis of chemical composition of precipitation in weldbraze

W kolejnych latach przeprowadzono szereg badań technologicznych procesu lutospawania łukowego w osłonie gazów z zastosowaniem niskoenergetycznych odmian procesów, takich jak CMT, ColdArc oraz lutospawania prądem o zmiennej biegunowości (Variable Polarity -GMA) [1,2,5]. Celem tych badań było określenie potencjalnego obszaru zastosowań nowoczesnych procesów lutospawania, a także zbadanie wpływu podstawowych parametrów technologicznych (napięcie łuku, natężenie prądu, prędkość przesuwu, rodzaj gazu osłonowego) na: przebieg procesu, jakość i budowę strukturalną połączeń oraz własności mechaniczne złączy wykonanych z blach stalowych z powłokami na bazie cynku (blachy karoseryjne). Badania wykazały, że wszystkie odmiany procesu lutospawania elektrodą topliwą w osłonach gazów zapewniają uzyskanie złączy lutospawanych charakteryzujących się bardzo dobrą jakością (rys. 8), minimalnym uszkodzeniem powłoki ochronnej, a także bardzo dobrymi własnościami mechanicznymi $[1,5]$. Precyzyjne sterowanie mikroprocesorowe parametrami procesu zapewnia stabilny przebieg i bardzo małą ilość odprysków (ok. 1\%). Dzięki mniejszej ilości wprowadzonego ciepła (lutospawanie w zakresie łuku zwarciowego, ograniczenie prądu zwarcia, zajarzanie łuku z minimalną wartością natężenia prądu) znacznie mniejsze jest nadto-

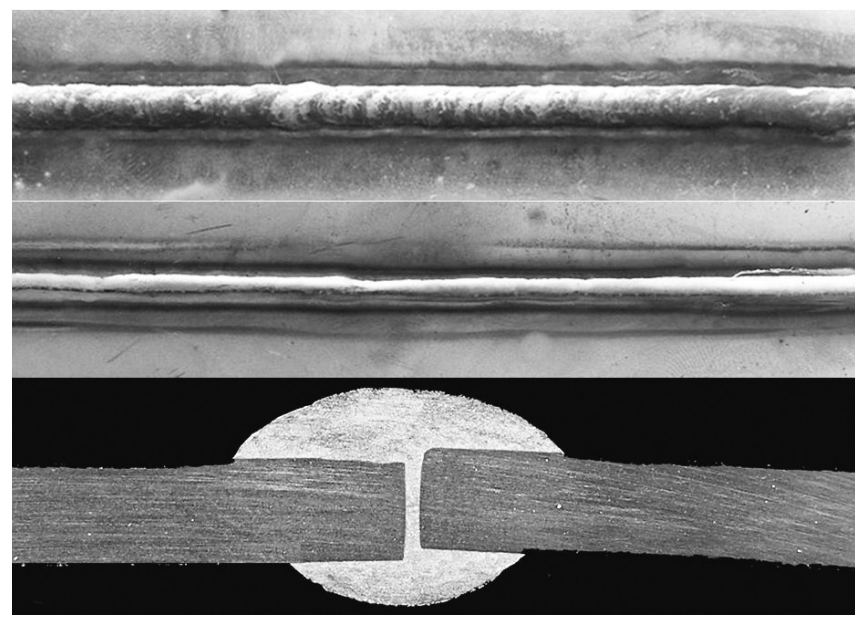

Rys. 8. Lico (a) i grań (b) oraz makrostruktura złącza doczołowego (c) blach ze stali ocynkowanej galwanicznie o grubości 1,5 mm lutospawanego metodą CMT

Fig. 8. The face (a) and root (b) side and macrostructure of $1,5 \mathrm{~mm}$ zinc coated steel butt joint made using CMT weldbrazing pienie krawędzi łączonych elementów, mniejsze są również odkształcenia. Estetyka połączeń jest również znacznie lepsza niż w przypadku lutospawania klasycznego prądem pulsującym. W Instytucie Spawalnictwa przeprowadzono również badania procesu lutospawania połączeń różnoimiennych stali ocynkowanej i nierdzewnej z aluminium oraz tytanu z aluminium. Wyniki tych badań zaprezentowano w innej publikacji znajdującej się w niniejszym numerze Przeglądu Spawalnictwa.

Jednym z obszarów badawczych w zakresie lutospawania blach stalowych ocynkowanych było określenie wpływu gazu osłonowego na jakość złączy, budowę strukturalną, a także własności mechaniczne. Przeprowadzone w Instytucie Spawalnictwa badania wykazały, że stosowanie jako gazu osłonowego mieszanek argonu z gazami utleniającymi $\left(\mathrm{CO}_{2}, \mathrm{O}_{2}\right)$ obniża napięcie powierzchniowe jeziorka spawalniczego, przez co poprawiają się warunki zwilżania i rozpływania stopionego spoiwa na materiale podstawowym (rys. 9). Zwiększa się też stabilność łuku i następuje poprawa wyglądu lica lutospoiny oraz zmniejsza się ilość odprysków. Mieszankę z tlenem można stosować wraz z lutami dobrze odtlenionymi, gdyż w innym przypadku może powstawać w lutospoinie tlenek miedzi $\left(\mathrm{CuO}_{2}\right)$, który gromadzi się na granicy ziaren i może być przyczyną kruchości i pęknięć pod wpływem naprężeń [9]. Badania wykazały, że wraz ze wzrostem indeksu oksydacyjnego mieszanki zwiększa się ilość wydzieleń faz międzymetalicznych w lutospoinie ze względu na znacznie większe nadtopienie materiału podstawowego [9]. Dla spoiw do lutospawania w postaci drutów proszkowych zaleca się stosowanie mieszanki argon-wodór $\left(\mathrm{Ar}+2 \% \mathrm{H}_{2}\right)$. Wodór w mieszance gazowej, podobnie jak tlen i dwutlenek węgla, poprawia stabilność łuku zwłaszcza przy stosowaniu niższych prądów spawania, podwyższa jakość i wygląd ściegu lutospoiny, a także oddziałuje odtleniająco na warstwę cynku w strefie łączenia. Jednak mieszanki argonu z tlenem, dwutlenkiem węgla lub wodorem wpływają na wprowadzenie większej ilości ciepła do strefy lutospawanej i mogą sprzyjać intensyfikacji utleniania lub nadtopienia powłok, zwłaszcza cynkowych (rys. 9) [5].

W Instytucie Spawalnictwa prowadzono również badania procesu lutospawania laserowego. Głównym ich celem było poznanie i opanowanie warunków prowadzenia procesu, a także opracowanie podstaw technologicznych lutospawania laserowego z wykorzystaniem nowoczesnej generacji laserów typu YAG i specjalnych głowic technologicznych z systemami śledzenia styku jakie dziś zaczynają być coraz 


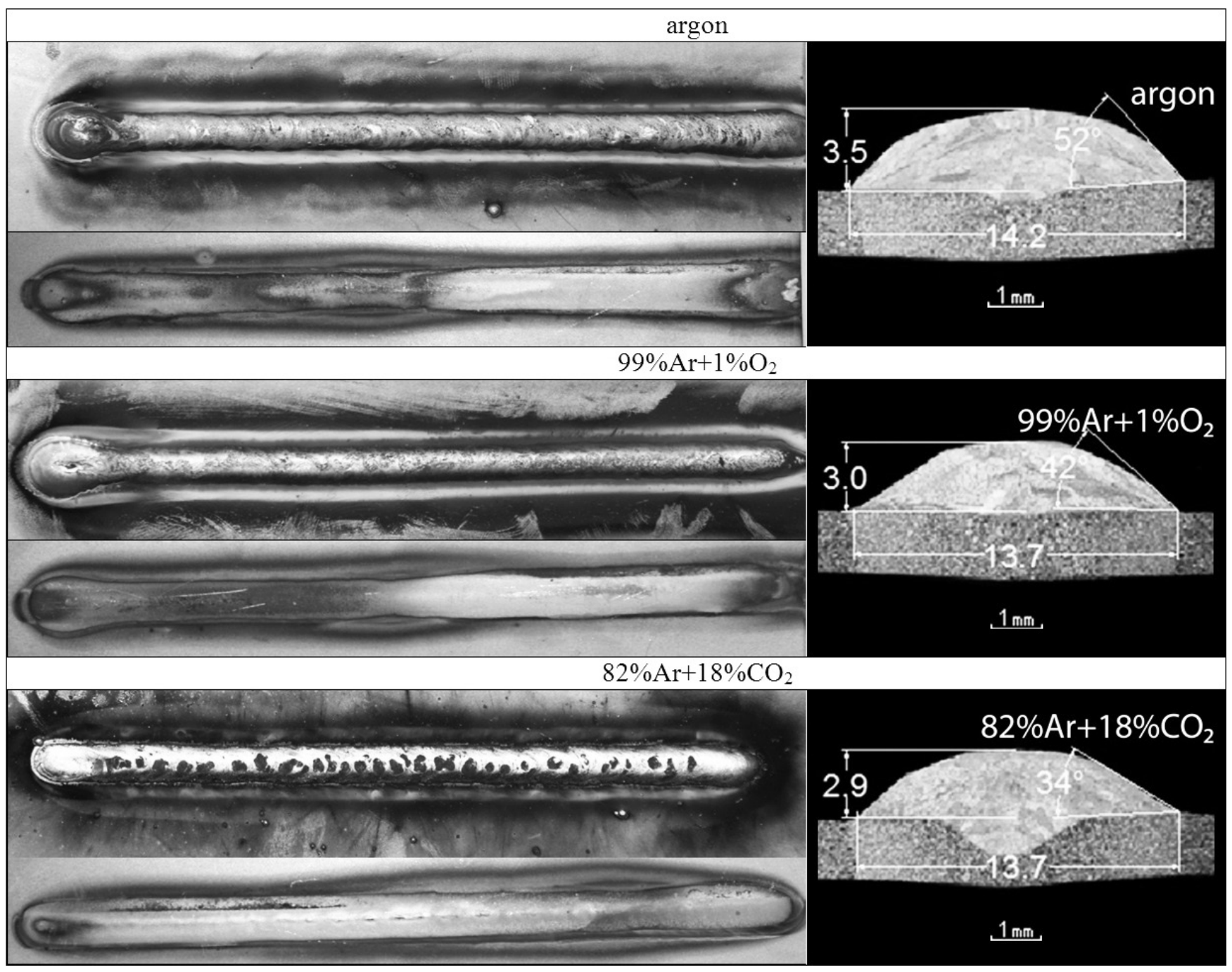

Rys. 9. Lico lutonapoiny, próbka od strony przeciwnej oraz makrostruktura lutonapoin wykonanych z zastosowaniem różnych gazów osłonowych

Fig. 9. Overlay brazes made using various shielding gases - view of the face and opposite side of the test piece of the overlay braze, overlay braze macrostructure (etching agent: Adler)

częściej stosowane w światowym przemyśle. Zakres badań obejmował określenie wpływu warunków i parametrów procesu na przebieg lutospawania laserowego i własności złączy wykonanych z blach stalowych z powłoką cynkową o grubości do 1,0 mm. Badania przeprowadzono na nowoczesnym stanowisku zrobotyzowanym, wyposażonym w laser dyskowy TruDisk 12002 Yb:YAG firmy Trumpf, robot
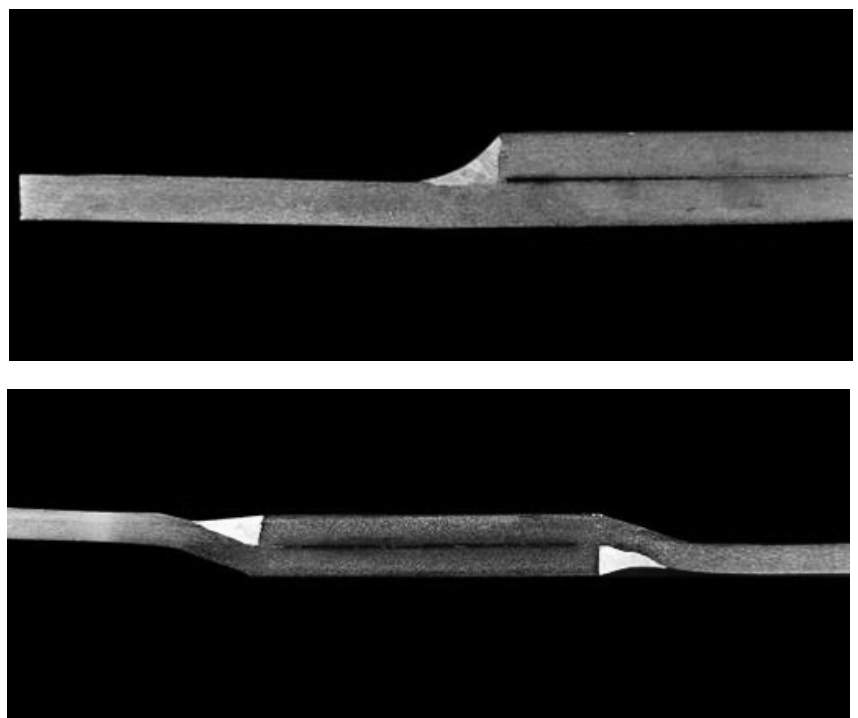

przemysłowy KUKA KRC30 HA i głowicę Scansonic ALO3 z taktylnym układem śledzenia styku w złączu.

Przeprowadzone badania technologiczne wykazały, że proces lutospawania laserowego przebiega stabilnie i pozwala uzyskiwać poprawne złącza, bez nadtopienia blach. Złącza charakteryzują się bardzo dobrą jakością i wysoką estetyką (rys.10).

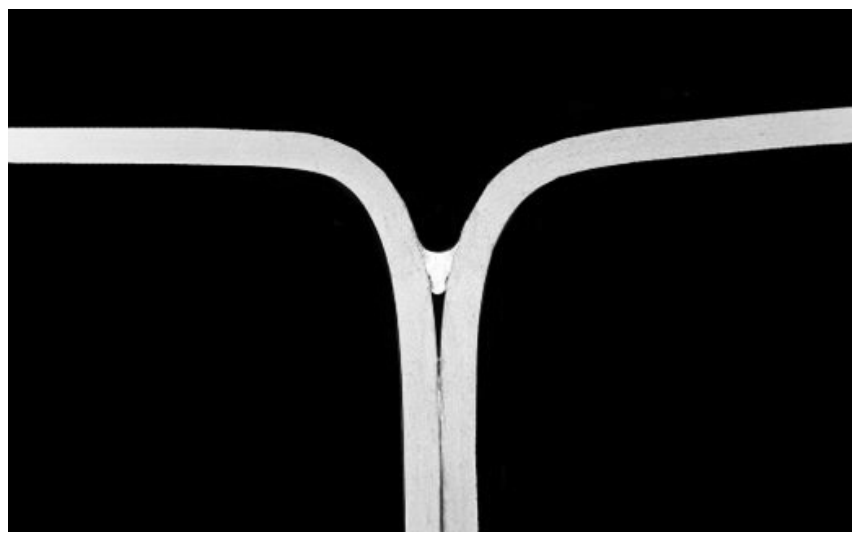

Rys. 10. Przykładowe makrostruktury złączy lutospawanych laserowo

Fig. 10. Examples of laser weldbrazed joints macrostructures 
Rejestracja procesu lutospawania laserowego umożliwiła poznanie jego przebiegu i zjawiska tworzenia się lutospoiny. W trakcie trwania procesu na powierzchni czołowej drutu tworzy się, w wyniku oddziaływania części przekroju plamki lasera, cienka, ciekła warstewka roztopionego metalu. Warstewka ta pod wpływem siły ciężkości spływa stabilnie w sposób ciągły do jeziorka roztopionego metalu tworząc z nim jeden wspólny obszar metalu w stanie ciekłym (rys. 11). Drut dolnym „ostrym” końcem jest dociskany i przesuwa się (ślizga) po powierzchni dolnej blachy. Przebiegający w ten sposób proces powoduje, że pozostała (poza cienką roztopioną warstewką) część drutu zachowuje dostateczną sztywność i może być dociskana do czołowej powierzchni górnej blachy siłą boczną służąc, jako „dotykowy sensor" taktylnego układu śledzenia. Taki przebieg procesu można uzyskać tylko w wyniku precyzyjnego doboru i korelacji wszystkich parametrów procesu: mocy, prędkości, trzech kątów ustawienia głowicy i siły bocznego docisku. Na początkowym stadium procesu, gdy metal nie jest jeszcze nagrzany, na końcu drutu może tworzyć się eliptyczna kropla (rys. 11) w zależności od parametrów procesu o średnicy ok. 2-3 razy większej niż średnica drutu. W tym czasie materiał lutospawany jest ciągle podgrzewany wiązką promieniowania laserowego. Po osiągnięciu odpowiedniej temperatury kropla z końcówki drutu rozpływa się na powierzchni blach tworząc ciekłe jeziorko, na czołowej powierzchni drutu tworzy się stabilna ciekła, cienka warstewka metalu połączona z jeziorkiem, a proces przyjmuje stabilny charakter.

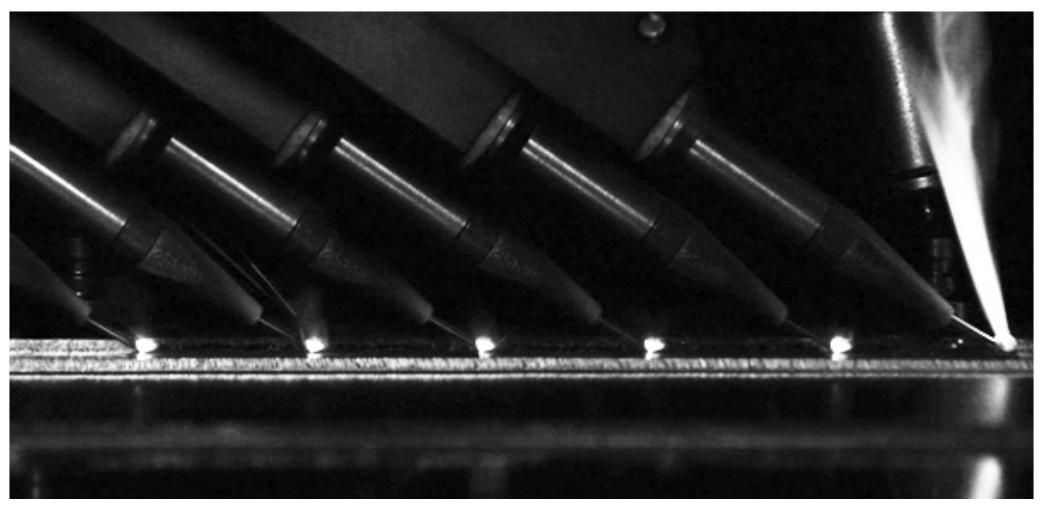

Rys. 11. Rejestracja fotograficzna (sekwencja nałożonych fotografii) procesu lutospawania laserowego złączy zakładkowych głowicą z taktylnym układem śledzenia

Fig. 11. Photographic recording (sequence of imposed photographs) of laser weldbrazing process of lap joints using of tactile tracking system head

\section{Podsumowanie}

Technologia lutospawania umożliwia łączenie elementów ze stali niestopowej z powłokami ochronnymi (cynkowymi, aluminiowymi), ze stali stopowej, a także wykonywanie połączeń różnoimiennych stali z aluminium i aluminium z tytanem. Technologia ta umożliwia również łączenie układów materiałowych, które uznawane są za niespawalne, np. żeliwo szare ze stalą do ulepszania cieplnego. Niska temperatura procesu i niewielka ilość wprowadzonego w obszar złącza ciepła, zapobiega uszkodzeniu powłoki ochronnej (lutospawanie laserowe i niskoenergetyczne odmiany metody MIG/MAG) lub powoduje, że jest ono minimalne (lutospawanie łukowe klasyczne). Dodatkowo powstająca w procesie lutospawania strefa wpływu ciepła jest znacznie węższa niż w przypadku spawania, a zachodzące w niej zmiany są minimalne.

Lutospawanie łukowe z zastosowaniem niskoenergetycznych procesów (CMT, ColdArc, AC-Pulse) umożliwia ograniczenie rozprysku, a także znaczne zmniejszenie odkształceń, zapewnia jednocześnie bardzo dobre własności mechaniczne i plastyczne połączeń. Lutospawanie laserowe zapewnia bardzo dobrą jakość i estetykę połączeń, a także bardzo wysoką wydajność procesu. Własności mechaniczne połączeń są również bardzo wysokie. Łatwość robotyzacji sprawia, że procesy lutospawania stosowane są coraz częściej w przemyśle motoryzacyjny w kraju i na świecie.

\section{Literatura}

[1] Matusiak J., Czwórnóg B., Pfeifer T.: Spawanie i lutospawanie niskoenergetycznymi metodami MIG/MAG przeznaczonymi do łączenia materiałów i elementów wrażliwych na ciepło, Biuletyn Instytutu Spawalnictwa, vol. 51 (6), s. 41-46, 2007.

[2] Matusiak J., Pfeifer T.: Niskoenergetyczne metody spawania łukowego w osłonie gazów - wpływ warunków materiałowo-technologicznych na jakość złączy i emisję zanieczyszczeń do środowiska pracy, Biuletyn Instytutu Spawalnictwa, vol. 52 (5), s. 85-92, 2008.

[3] Quintino L., Pimenta G., Iordanescu D., Miranda R., Pepe N.: MIG brazing of galvanized thin sheets for automotive industry, Materials and Manufacturing Processes, vol. 21 (1), s. 63-73, 2006.

[4] Joseph A., Webb C., Haramia M., Yapp D.: Variable polarity improves weld brazing of galvanized sheet, Welding Journal, vol. 80 (10), s. 36-40, 2001

[5] Pikuła J., Mendakiewicz J., Pfeifer T.: Wpływ gazu osłonowego na własności połączeń blach ocynkowanych wykonanych metodą lutospawania MIG/MAG prądem o zmiennej biegunowości, Biuletyn Instytutu Spawalnictwa, vol. 58 (1), s. 54-59, 2014.

[6] Klimpel A., Czupryński A., Górka J.: Lutospawanie plazmowe proszkowe PTA złączy blach karoseryjnych galwanizowanych cynkiem, Przegląd Spawalnictwa, nr 9, s. 26-31, 2007.

[7] Banasik M., Stano S., Dworak J.: Lutospawanie laserowe na stanowiskach zrobotyzowanych, Biuletyn Instytutu Spawalnictwa, vol. 56 (5), s. 134-139, 2012.
[8] Klimpel A., Czupryński A., Górka J.: Lutospawanie laserowe ocynkowanych blach karoseryjnych, Biuletyn Instytutu Spawalnictwa, vol. 50 (6), s. 39-43, 2006.

[9] Gawrysiuk W.: Technologia lutospawania łukowego. Zalecenia technologiczne i przemysłowe przykłady zastosowań, Biuletyn Instytutu Spawalnictwa, vol. 49 (3), s. 35-40, 2005.

[10] Różański M., Gawrysiuk W.: Lutospawanie MIG/MAG blach ocynkowanych i przykłady trudno spawalnych układów materiałowych, Przegląd Spawalnictwa, nr 9, s. 7-12, 2007.

[11] Mirski Z., Granat K.: Lutospawanie gazowe ocynkowanych rur stalowych, Przegląd Spawalnictwa, nr 2-3, s. 19-21, 2003.

[12] T. Strite, A. Gusenko, M. Grupp, T. Hoult: Lasery włóknowe w zastosowaniu do obróbki materiałów za pomocą wielokrotnej wiązki laserowej, Biuletyn Instytutu Spawalnictwa, vol. 60 (3), s. 46-48, 2016.

[13] A. Czupryński, T. Kik, J. Górka: Wykorzystanie niskoenergetycznego procesu CBT do łączenia stali wysokostopowej z miedzią, Przegląd Spawalnictwa, vol. 87 (nr 5), s. 21-31, 2015.

[14] A. Czupryński, D. Janicki: Przyczyny pęknięć lutospoin w złączach różnoimiennych typu aluminium-ocynkowana stal niestopowa, Przegląd Spawalnictwa, vol. 88 (nr 5), s. 43-48, 2016. 